\title{
原著論文
}

\author{
下顎側方移動による蝸牛の機能変化 \\ 竹村雅宏, 松本敏彦* \\ 日本大学大学院松戸歯学研究科局部床義歯学専攻 \\ *日本大学松戸歯学部歯科補綴学第三講座 \\ 〔受付：平成16年11月 8 日]
}

\section{Changes of cochlear function stemming from jaw side shift}

\author{
Masahiro Takemura, Toshihiko Matsumoto* \\ Nihon University Graduate School of Dentistry at Matsudo, \\ ${ }^{*}$ Department of Removable Partial Prosthodontics, Nihon University School of Dentistry at Matsudo
}

[Recieved: November 8, 2004.]

Key Word: mandibular position, distortion product otoacoustic emission (DPOAE), cochlear function

\begin{abstract}
This study was conducted to investigate the functional change of auditory path way stemming from jaw position. Therefore, we measured tympanogram and distortion product otoacoustic emission in closed position and canine apical position (lateral position) of 11 healthy subjects, and reviewed a functional change of auditory pathway by mandibular lateral move.

1. The incisal point moved $0.8(1.1) \mathrm{mm}$ in sagittal direction $(\mathrm{X}), 3.8(0.9) \mathrm{mm}$ in lateral direction (Y), 2.8 (1.3) $\mathrm{mm}$ in vertical direction $(\mathrm{Z})$. In the condyle point, working side (WS) moves $0.2(0.3) \mathrm{mm}$ in front direction, $0.3(0.3)$ $\mathrm{mm}$ in outside direction, $0.3(0.5) \mathrm{mm}$ in a downward course. The inclination of sagittal condyle path was 23.7 $(59.3)^{\circ}$, lateral condyle path was $-4.7(63.1)^{\circ}$. The non-working side (NWS) moved $2.9(1.2) \mathrm{mm}$ in front direction, $0.5(0.4) \mathrm{mm}$ in an inside direction, $3.3(1.3) \mathrm{mm}$ in a downward course. The inclination of sagittal condyle path was $49.6(6.8)^{\circ}$, lateral condyle path was $9.6(7.0)^{\circ}$.

2. In tympanogram, WS showed significant decline in IMP, but the difference was not recognized in PRS and EAC. The difference was recognized in neither in NWS for this.

3. A DP level of lateral position showed significant degradation at $2000 \mathrm{~Hz}$ and elevation at $5031 \mathrm{~Hz}$ in WS. On the other hand, it recognized a significant rise at $1250 \mathrm{~Hz}$ and $5031 \mathrm{~Hz}$, degradation at $2000 \mathrm{~Hz}$ in NWS. The change was not accepted with other frequency.

4. Correlation with quantity of displacement to lateral position and quantity of DP level change is accepted. In incisal point, positive correlation was accepted between $\mathrm{Z}$ and $1250 \mathrm{~Hz}$, between $\mathrm{Y}$ and $2000 \mathrm{~Hz}$, negative correlation was accepted between $\mathrm{Z}$ and $2531 \mathrm{~Hz}, 5031 \mathrm{~Hz}$ in WS. However, the significance was not recognized in all measured value in NWS. At condyle point, positive correlation was accepted between inclination of lateral condyle path and $2531 \mathrm{~Hz}$ in WS, but the reference was recognized in neither between other measured value.
\end{abstract}

連絡先：テ271-8587 千葉県松戸市栄町西 2-870- 1

TEL: 047-360-9389 FAX: 047-360-9389 
From these results, it was suggested that mandibular position had an influence on auditory pathway, the change on auditory pathway was recognized in the response threshold of a DP level.

抄録 本研究は，生理的な下顎側方移動に伴う聴覚路の機能変化について検討を行った。健常有歯顎者 11 名の閉口位と犬歯尖端位（側方位）におけるティンパノグラムおよび歪成分耳音響放射を測定した結果，

1. 下顎切歯点は, 前方に0.8 $(1.1) \mathrm{mm}$, 側方に3.8 $(0.9) \mathrm{mm}$, 下方に $2.8(1.3) \mathrm{mm}$ に移動し, 顆頭点は作業 側で前方に $0.2(0.3) \mathrm{mm}$, 外方に0.3 $(0.3) \mathrm{mm}$ ，下方に0.3(0.5) $\mathrm{mm}$ 移動した。このときの顆路角は矢状 顆路角 $23.7(59.3)^{\circ}$ ，側方顆路角 $-4.7(63.1)^{\circ}$ であった．非作業側では，前方に $2.9(1.2) \mathrm{mm}$, 内方に0.5 (0.4) $\mathrm{mm}$, 下方に3.3 (1.3) $\mathrm{mm}$ 移動し, 顆路角は矢状顆路角 $49.6(6.8)^{\circ}$, 側方顆路角9.6(7.0)。であった.

2.ティンパノグラムは, 作業側耳では鼓膜インピーダンスは有意に減少したが, 中耳腔圧と中耳腔容積 の変化は認められなかった. 非作業側耳では，いずれにも変化はみられなかった.

3. DP レベルは，作業側耳では $2000 \mathrm{~Hz}$ で有意に低下し，5031Hz で有意に上昇した．他方，非作業側耳 では $1250 \mathrm{~Hz}$ および $5031 \mathrm{~Hz}$ で有意に上昇し，2000Hz で有意に低下した．他の周波数では変化はみら れなかった。

4. 側方移動量と DP レベル変化量との相関関係は, 切歯点側方移動量と作業側耳の $2000 \mathrm{~Hz}$, 垂直移動量 と作業側耳の $1250 \mathrm{~Hz}$ にそれぞれ正の相関，2531Hz および $5031 \mathrm{~Hz}$ に負の相関が認められた。しかし 非作業側耳においては全測定值で有意性は認められなかった．他方，顆頭点の変化との相関関係は， 作業側側方顆路角と $2531 \mathrm{~Hz}$ にのみ正の相関が認められたが，他の測定値間のいずれにも関係はみら れなかった。

以上の結果より, 下顎側方運動において, 中耳腔の圧や容積の変化がみられず, その変調は鼓膜インピー ダンスおよびDP レベルに認められたことから，下顎位の変化が聴覚路に及ほす影響は三叉神経の感覚受 容の変化であることが示唆された.

キーワード 下顎位, 歪成分耳音響放射, 蝸牛機能

\section{I. 緒 言}

下顎位による聴覚機能障害の報告 ${ }^{1)}$ 以来, 耳の機能異 常の発症機序は後方偏位した下顎頭による機械的圧力か ら三叉神経の異常興奮の聴器への投射へと変遷し, ツチ 骨前䩲帯の発見や蝶下顎䩲帯を介した中耳と顎関節の靫 帯接続，三叉神経節による蝸牛および前庭迷路膨大部稜 など内耳血管系の支配も明らかになった．他方，咬合治 療の臨床への他覚的検査法の応用以後, 種々の臨床的検 討を経て中耳機能を判断指標とした顎位設定法が医療承 認され ${ }^{2)}$ ，顎関節症の病態評価や治癒判断における新し い指標を示唆している。それらは，顎機能障害における 蝸牛の高周波帯域 DP レベルの低下や咬合治療による変 化 $^{3)}$, 遠心路の反射波形の振幅減少や反射閾值の上昇 ${ }^{4)}$, 非耳性耳痛へのアブミ骨筋の関与や反射間値上昇に下 顎頭の捻転を示唆し ${ }^{5)}$, 生理的下顎位の他覚的把握 ${ }^{6,7)}$ も期待される.

しかし，鼓膜インピーダンスの変化は健常者や咬合支 持喪失者の咬合高径の変化にも認められ ${ }^{6,7)}$ ，耳小骨筋 反射の波形潜時を変化させるが, 反射閾值に変化は認め
られていない ${ }^{7)}$. これらの知見は, 生理的な下顎の移動 と顎偏位に対する蝸牛神経の応答機序の相違を示唆する ものの，いまだ明らかではない.したがって，健常者に おける下顎頭運動による中耳伝音系や蝸牛神経の機能変 化およびその応答様相を把握することは極めて重要であ ると考えられる。

そこで本研究では, 健常者における閉口位と側方運動 の犬歯尖端位（以下，側方位）の 2 顎位で聴覚路の応答 様相を測定し, 移動距離を切歯点と顆頭点で測定して関 連の有無を検討した。

\section{II. 被検者と方法}

\section{1. 被検者}

顎関節および耳鼻咽喉領域の病歴がなく，耳科学的に 中耳伝音系が機能正常と診断されるティンパノグラム $\mathrm{A}$ 型の個性正常咬合有歯顎者ボランティア11名（男性, 平 均 27.0歳）を対象とした.

\section{2. 方法}

被検者は治療椅子に垂直座位で頭部は安頭台にて支持 
し, 閉口位（以下, CP） から側方位への下顎移動を切 歯点と顆頭点で同時測定し，この 2 顎位におけるティン パノグラムおよび歪成分耳音響放射を測定した.

\section{1 ）側方移動}

閉口位から側方位への犬歯誘導による側方滑走運動 の切歯点移動距離は Mandibular kinesiograph K6-I (MYOTRONICS, USA）により，顆頭点移動距離掞よび顆路角 は CADIAX COMPACT (Gamma, Austria) により，それ ぞれ測定した。

\section{2) 中耳機能}

インピーダンス・メーターMA-4000（モリタ）によ り，ティンパノグラムを測定した. ティンパノグラムに 表示される鼓膜インピーダンス（以下，IMP)，IMPが 最小值を示すときの中耳腔と等価の閉鎖外耳道の圧（以 下, PRS）および中耳腔の容積（以下， EAC）を中耳機 能の測定值とした．ティンパノグラムとは，音響反射 を指標とした中耳伝音系の非侵襲的な他覚的機能検査 法（ティンパノメトリー）から得られる波形表示で $3 つ$ の型に分類されている．A 型は伝音機能正常を示し， $\mathrm{A}_{s}$ 型は耳小骨連鎖固着, $\mathrm{A}_{\mathrm{D}}$ 型は耳小骨連鎖離断や鼓膜萎 縮， $\mathrm{B}$ 型は淩出性中耳炎や癒着性中耳炎， C 型は耳管狭 窄症や渗出性中耳炎を疑うとされる．本研究の対象とし た $\mathrm{A}$ 型被検者は, 伝音系機能正常を診断する基準となっ ている.

\section{3 ) 螖牛神経機能}

GSI-60 DPOAE system（Lucas Grason Stadler, USA）を 用い, 蝸牛外有毛細胞の能動的活動を測定し, 歪成分 耳音響放射 (distortion-product otoacoustic emission, 以下, DPOAE）の応答（DPレベル， dBSPL）により評価し た. DPOAE とは，内耳への 2 つの入力信号音 $\mathrm{f}_{1}, \mathrm{f}_{2}$ が 聴覚系の非線形性により基底板に歪振動を発生させる ので，その 3 次の結合音 $2 \mathrm{f}_{1}-\mathrm{f}_{2}$ が蝸牛より逆行性に放射 される。本機はノートブック型コンピュータ ARMADA E-500（Compaq, USA）の DSPボード, 刺激音呈示用の スピーカーとマイクロフォンを備えたプローブで構成さ れ，プローブから発した 2 つの入力信号音 $\mathrm{f}_{1}, \mathrm{f}_{2}$ の 3 次 の結合音 $2 \mathrm{f}_{1}-\mathrm{f}_{2}$ を FFT 分析する. $\mathrm{f}_{2} / \mathrm{f}_{1} \fallingdotseq 1.2, \mathrm{f}_{1}$ は 1000 $5031 \mathrm{HZ}, \mathrm{f}_{2}$ は $1187 \sim 6031 \mathrm{~Hz}$ で1/3オクターブごと， 8 周 波数点の DP レベルが測定できる. 本研究では $\mathrm{f}_{1}, \mathrm{f}_{2}$ の 入力音圧70dBSPL で自動測定した。呼吸の干涉や信頼 性の点から $1000 \mathrm{~Hz}$ 以下は考慮外とし, $1250 \mathrm{~Hz}$ 以上の 5 周波数点の DP レベルを対象とした.

\section{4 ）データの取り扱いと分析}

下顎側方移動では，右方向および左方向のいずれの測 定值にも差が認められず，CPにおける測定值について
も左右差が認められなかったので，側別を廃し一括して 22 耳として取り扱った。側方位のティンパノグラム，反 射閾值, 波形潜時 $\mathrm{L}_{1}$, DP レベルの測定值は，作業側（以 下，WS），非作業側（以下，NWS）と同側耳とし，CP とWS, CP と NWS それぞれの測定值の差を算出して, 変化量とみなした。分析には StatView 5.0J (SAS) を用 い, 䫴位変化による聴覚機能変化の有無はWilcoxonの 符号順位検定にて行い, 切歯点の移動距離顆頭点移動距 離および顆路角とDPOAE 変化量との相関関係の有無は Spearmanの順位相関係数により検討した。いずれも危 険率 $\mathrm{p}<0.05$ をって有意とした。

\section{III. 結 果}

\section{1. 切歯点移動距離, 顆頭点移動距離および顆路角}

切歯点移動距離は表 1 に, 顆頭点の移動距離, 顆路角 は表 2 に示した．顆頭点の側方移動量は，正値が内方移 動, 負值が外方移動を示した。

2. ティンパノグラム

測定結果は表 3 に示した．側方移動によって，WS で は, 危険率 $1 \%$ で，IMP は有意に減少したが, PRS と EAC には差違は認められなかった。これに対してNWS では，いずれにも差違はみられなかった。

\section{3. 歪成分耳音響放射}

DP レベルを表 4 に示した．側方位 DP レベルは危険 率 $5 \%$ で, WS では $2000 \mathrm{~Hz}$ で有意に低下し，5031Hzで 有意に上昇した。他方，NWS では $1250 \mathrm{~Hz}$ および $5031 \mathrm{~Hz}$ で有意に上昇し， $2000 \mathrm{~Hz}$ で有意に低下した。他の周波 数では変化はみられなかった.

\section{4 . 側方位への移動量と DP レベル変化量との相関}

切歯点の移動距離とDP レベルとの相関表は表 5 に, 顆頭点の移動距離㧍よび顆路角とDP レベルとの相関表 は表 6 に示した．切歯点では WS の Y 值と $2000 \mathrm{~Hz}$ に正 の相関，WS の Z 值と $1250 \mathrm{~Hz}$ に正の相関， $2531 \mathrm{~Hz}$ およ び5031Hzに負の相関が認められた。しかしNWSにお いては全測定值で有意性は認められなかった。他方, 顆 頭点では，WS の側方顆路角と $2531 \mathrm{~Hz}$ にのみ正の相関 が認められたが，他の測定值間のいずれにも関係はみら れなかった。 
表 1 下顎側方移動による切歯点の変化

Table 1 Changes of incisal point in lateral shift

\begin{tabular}{cccc}
\hline \hline & $X$ (前後) & $Y$ (左右) & $\mathrm{Z}$ (上下) \\
\hline Mean & 0.8 & 3.8 & 2.8 \\
S. D. & $(1.1)$ & $(0.9)$ & $(1.3)$ \\
\hline
\end{tabular}

注) 移動方向の数値はX (前後)では前方移動が正値, 後 方移動が負値となる．Y (左右)は側方移動量を示す．Z (上下) は下方移動が正值，上方移動が負値となる.

したがって, 3.8(0.9) $\mathrm{mm}$ の下顎側方移動による切歯 点の移動は, 前方に0.8(1.1), 下方に2.8(1.3) となった.
表 3 下顎側方移動によるティンパノグラムの変化

Table 3 Changes of Tympanogram stemming from lateral shift of mandibule

\begin{tabular}{|c|c|c|c|c|}
\hline & & IMP (ohm) & PRS (daPa) & $\mathrm{EAC}(\mathrm{ml})$ \\
\hline \multirow{3}{*}{ Ear } & $\mathrm{CP}$ & $\underset{*}{2295}\rceil$ & $\begin{array}{c}-6.5 \\
(4.0)\end{array} \prod_{\text {n.s. }}$ & $\begin{array}{l}0.83 \\
(0.16) \\
\mathrm{n}\end{array}$ \\
\hline & WS & $\frac{2226}{(960)}$ & $\begin{array}{l}-7.1] r \\
(4.8)\end{array}$ & $\begin{array}{l}0.81 \\
(0.14)\end{array}$ \\
\hline & NWS & $\begin{array}{l}2308 \\
(1161)\end{array}$ & $\begin{array}{l}-7.9 \\
(4.5)\end{array}$ & $\begin{array}{l}0.86 \\
(0.17)\end{array}$ \\
\hline
\end{tabular}

Mean,(S.D.), Wilcoxon's signed-rank test, $* *: \mathrm{p}<0.01$

表 2 下顎側方移動による顆頭点の変化

Table 2 Changes of condyle point in lateral shift

\begin{tabular}{lccccc}
\hline \hline & $\begin{array}{c}\text { 前後方向 } \\
(\mathrm{mm})\end{array}$ & $\begin{array}{c}\text { 内外方向 } \\
(\mathrm{mm})\end{array}$ & $\begin{array}{c}\text { 上下方向 } \\
(\mathrm{mm})\end{array}$ & $\begin{array}{c}\text { 矢状顆路角 } \\
(\circ)\end{array}$ & $\begin{array}{c}\text { 側方顆路角 } \\
(\circ)\end{array}$ \\
\hline \multirow{2}{*}{ WS } & 0.20 & -0.25 & 0.26 & 23.71 & -4.67 \\
& $(0.28)$ & $(0.29)$ & $(0.45)$ & $(59.28)$ & $(63.06)$ \\
\multirow{2}{*}{ NWS } & 2.88 & 0.50 & 3.34 & 49.59 & 9.57 \\
& $(1.18)$ & $(0.38)$ & $(1.27)$ & $(6.78)$ & $(7.04)$
\end{tabular}

Mean,(S.D.)

注）移動方向の数値は前後では前方が正值, 後方が負值, 内外では内方が正值, 外方が負値, 上下では下方が正値，上方が負值を意味する.

顆路角は FH 基準より下方に移動した角度は正值，上方に移動した角度は負值を示す. 側方では内方に移動した角度は正値, 外方に移動した角度は負值を示す。

表 4 下顎側方移動による DP レベルの変化

Table 4 Change of DP level stemming from lateral shift of mandible

\begin{tabular}{|c|c|c|c|c|c|c|}
\hline & $f_{1}$ & 1250 & 2000 & 2531 & 4000 & $5031(\mathrm{~Hz})$ \\
\hline \multirow{3}{*}{ Ear } & $\mathrm{CP}$ & $\begin{array}{l}7.0 \\
(7.0)\end{array}$ & $\begin{array}{l}5.9 \\
(3.1)\end{array}$ & $\begin{array}{l}4.3 \\
(4.6)\end{array}$ & $\begin{array}{l}5.8 \\
(4.6)\end{array}$ & $\begin{array}{c}4.7 \\
(5.1)\end{array} T_{*}$ \\
\hline & WS & $\begin{array}{l}7.2 \\
(7.1)\end{array}$ & $\begin{array}{l}5.1 \\
(3.9)\end{array}$ & $\begin{array}{l}4.5 \\
(3.9)\end{array}$ & $\begin{array}{l}6.2 \\
(4.2)\end{array}$ & $\begin{array}{l}5.7 J_{*} \\
(5.5)\end{array}$ \\
\hline & NWS & $\begin{array}{l}8.1 \\
(5.9)\end{array}$ & $\begin{array}{l}5.2 \\
(3.6)\end{array}$ & $\begin{array}{l}4.3 \\
(4.0)\end{array}$ & $\begin{array}{l}5.6 \\
(5.1)\end{array}$ & $\begin{array}{l}5.7 \\
(5.7)\end{array}$ \\
\hline
\end{tabular}


表 5 DP レベルと切歯点移動距離との関連

Table 5 The correlation coefficient between DP level and lateral shift at incisal point

\begin{tabular}{rcrrrrr}
\hline \hline$f_{1}$ & & 1250 & 2000 & 2531 & 4000 & 5031 \\
\hline \multirow{2}{*}{$X$} & WS & 0.04 & 0.16 & 0.13 & 0.24 & 0.20 \\
& NWS & -0.28 & -0.31 & -0.27 & -0.38 & -0.19 \\
\hline \multirow{2}{*}{$Y$} & WS & 0.14 & $0.55 *$ & -0.04 & -0.12 & 0.01 \\
& NWS & -0.13 & 0.23 & 0.07 & -0.09 & 0.02 \\
\hline \multirow{2}{*}{$Z$} & wS & $0.51 *$ & -0.01 & $-0.46 *$ & -0.31 & $-0.60 * *$ \\
& NWS & 0.06 & 0.15 & -0.06 & 0.16 & -0.10 \\
\hline
\end{tabular}

Spearman's correlation coefficient by rank, $*$ : $\mathrm{p}<0.05, * *: \mathrm{p}<0.01$

表 6 DP レベルと顆頭点移動距離・角度との関連

Table 6 The correlation coefficient between DP level and values of condyle movement in mandibular lateral shift

\begin{tabular}{ccrrrrr}
\hline \hline$f_{1}$ & & 1250 & 2000 & 2531 & 4000 & $5031(\mathrm{~Hz})$ \\
\hline \multirow{2}{*}{ 前後方向 } & $W S$ & 0.04 & -0.02 & -0.25 & -0.12 & -0.20 \\
& $N W S$ & -0.12 & -0.05 & 0.00 & 0.01 & 0.01 \\
\hline \multirow{2}{*}{ 内外方向 } & WS & 0.09 & -0.02 & 0.19 & 0.03 & 0.22 \\
& NWS & 0.07 & 0.27 & 0.26 & -0.22 & -0.07 \\
\hline \multirow{2}{*}{ 上下方向 } & WS & -0.12 & -0.20 & -0.32 & 0.05 & 0.03 \\
& NWS & -0.23 & 0.23 & 0.20 & -0.07 & -0.05 \\
\hline \multirow{2}{*}{ 矢状顆路角 } & WS & 0.11 & -0.41 & -0.23 & -0.05 & -0.29 \\
& $N W S$ & -0.03 & 0.34 & 0.16 & -0.26 & -0.18 \\
\hline \multirow{2}{*}{ 側方顆路角 } & WS & -0.35 & -0.22 & $0.53 *$ & 0.29 & 0.34 \\
& $N W S$ & 0.09 & 0.33 & 0.24 & -0.23 & 0.00
\end{tabular}

Spearman's correlation coefficient by rank, $*: \mathrm{p}<0.05$

\section{N. 考察}

\section{1. 側方移動による切歯点と顆頭点の変化について}

閉口位から犬歯切端位への切歯点の移動を前後 $(\mathrm{X})$, 側方 $(\mathrm{Y})$, 上下 $(\mathrm{Z})$ の 3 つの成分とした. 本結果では, $\mathrm{Y}$ 值は上顎犬歯の歯冠傾斜の水平面投影距離を, $\mathrm{Z}$ 值 は前頭面観投影距離に相当する．Y 值は3.8 $(0.9) \mathrm{mm}$ で, Ingervall $^{8)}$ の值に近似した。下顎離開（canine lift）を意 味する Z 值は2.8(1.3) $\mathrm{mm}$ で, 計算上の誘導路角はほほ $73^{\circ}$ となる. 矢状方向の変化量 $\mathrm{X}$ 值は正值を示したこと から, 本被検者の犬歯誘導は $\mathrm{M}$ 型と推測される.
顆頭点の移動ではWS の傾斜角度の標準偏差は著しく 大きく, 側方顆路角は負值を示した. これは, 側方運 動における作業側顆頭運動の多様性を示し, 健常者の犬 歯誘導における下顎頭の下方移動を示唆すると考えられ た.この点に関して Aull ${ }^{9)}$ は後上方を除きあらゆる方 向を示すと報告しており, 中野 ${ }^{10)}$ は移動距離や方向が 複雑多様であると述べている. 本研究で用いた顆頭点運 動の測定装置 CADIAX COMPACT は, 電子式顎運動解 析装置で, そのシステムから WS の移動傾斜角は, Aull ${ }^{9)}$ や中野 ${ }^{10)}$ と同様の結果を示すものと考えられた. 


\section{2. ティンパノグラムの変化について}

WS では IMP は有意に減少したが, NWS では変化が みられなかった。これらの結果は, 酒井 ${ }^{6)}$ 以後の教室 の報告と一致している ${ }^{11,12)}$ 。また, PRS およびEACに は，WS，NWSいずれにも変化はみられなかった。 この 点について, 黑滝ら ${ }^{13)}$ は開口運動と中耳コンプライア ンスを同時間測定し，コンプライアンスの変化が中耳 腔と外耳腔との圧差ではないとし, 田沼ら ${ }^{14)}$ はPRS が Immediate Side Shift とのみ相関性を示したとしている. WS, NWS いずれでも PRS およびEAC が変化を示さな かったことは, 閉口位から犬歯切端位への移動という生 理的運動では下顎頭位の変化は中耳腔の圧や容積に影響 を及はさないといえる。したがって下顎側方移動による 本被検者の鼓膜インピーダンスの変化は, 作業側下顎頭 の運動に対する鼓膜の三叉神経感覚受容の変化と考えら れる。

3. DPOAE の変化について

蝸牛には基底板からの距離に従い周波数に対する部位 特異性があるとされ，外有毛細胞が大きく関与している と考えられている. DPOAE は, 外有毛細胞を主とした組 織学的障害部位と非常に高い周波数特異性を有する ${ }^{15,16)}$ ことが証明され, 入力周波数により蝸牛の部位別の機 能評価が可能である. DPOAEの変化の機序について Telischi $~^{17)}$, Mom ${ }^{18)}$ は DPOAE が内耳血流に敏感に 応答することを報告しているが，このことはVass ら ${ }^{19,20)}$ によって，内耳血管系の三叉神経支配が証明されている ことから, 下顎移動に伴う三叉神経節の異常感覚受容が 内耳血管系へと投射され, 蝸牛神経の機能変化が惹起さ れる可能性が示唆される.

しかし，顎関節と蝸牛との神経機能の連繋について の報告は少ない. 菊池 ${ }^{3)}$ は顎機能障害における蝸牛基 底回転部の高周波数帯域の DP レベル低下を認め, 内耳 の機能障害の初期像であるとしている. Sobhy ${ }^{21)}$ は耳 鳴を伴う顎機能障害における DPOAE の症状消退に伴う 変化を認め,三叉神経刺激による蝸牛機能の変化を示唆 している。鎌田 ${ }^{22)}$ は無難聴性耳鳴症例における $4000 \mathrm{~Hz}$, $5031 \mathrm{~Hz}$ の DP レベルが有意に低下するとし，基底回転 の外有毛細胞の機能変化を報告している。これらは顎機

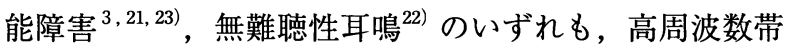
域の DP レベルの低下を示唆している.

DPOAE は外耳道から音刺激を与え, 内耳からの音響 放射を外耳道で受け取ることになり入出力双方で中耳 の影響を受けることになる。 ヒトの中耳共振周波数は $1 \mathrm{kHz} 1.5 \mathrm{kHz}$ 付近に存在するとされ ${ }^{24)}$, この周波数帯域 においては伝達効率の変化は無視できないと考えられ
る. 作業側耳のみにおいて顆頭点運動と DP レベルとの 相関がみられたことは，下顎移動に伴う伝音系や蝸牛の 機能変化が単なる機械的圧迫による血流変化ではないこ とを示唆する. Nagai $5^{25)}$ は鼓膜には機械的刺激に反応 する神経終末が存在することを明らかにしており，この 点から考えると機械的刺激による三叉神経の感覚受容性 に変化が生じると考えられる.下顎頭の移動により中耳 腔の圧や容積は変化しない尚, 14) ので, 表 3 に示される IMP の変化は神経的な影響と考えられる. しかしながら ティンパノグラムに大きな変化は認められず，共振周波 数に影響を与えるとされる中耳伝音系の stiff が生じて いる可能性は少ない. Vass $ら^{19,20)}$ の報告の機序を考え ると, 下顎側方移動による三叉神経節の感覚が直接蝸牛 に投射する可能性も否定できないが，中耳の機械的作用 の影響は考えにくく, 蝸牛神経の感覚受容の変化と考え られる。

本研究の結果は表 4 に示したように,WS, NWS の $2000 \mathrm{~Hz}$ で統計的に有意な DP レベルの低下が認められ, NWS $~ 1250 \mathrm{~Hz}$ と $5031 \mathrm{~Hz}$, WS の $5031 \mathrm{~Hz}$ で統計的に有 意な DP レベルの上昇が認められた，基底部に近接する 高周波帯域では上昇, 中周波帯域では低下, 頂回転に 近い低周波带域では上昇という傾向がみられる。中耳の 影響の少ない高周波帯域㧍よび，中周波帯域では，WS， NWS ともに同様の変化として認められる. しかしなが ら, 下顎頭の位置的変化は, WS は前下外方へ, NWS は前下内方へ異なった変化を示した. したがって下顎頭 の移動に伴う機械的作用とは考えにくく, 側方移動に伴 う三叉神経への刺激が両側性にオリーブ螖牛束に影響を 及ほす可能性が考えられた。

\section{DPOAE と側方位への移動との関連性について}

切歯点の側方移動とこれに伴う WS 耳, NWS 耳 のDPOAE との相関表は, 表 5 に示した. WS では, $2000 \mathrm{HzDP} レ$ ルと Y，1250HzDPレベルと Z，それぞ れの間で有意な正の相関が認められ，2531Hz および $5031 \mathrm{~Hz}$ の DP レベルと Z との間では有意な負の相関が 認められた。これらは, 側方位への水平的距離の増大が 作業側耳 $2000 \mathrm{~Hz}$ の DP レベルを上昇させることを意味 し, 臨床において歯冠による canine lift は $1250 \mathrm{~Hz}$ の DP レベルを上昇させ， $2531 \mathrm{~Hz}$ および $5031 \mathrm{~Hz}$ の DP レベル を低下させることを示唆する。

本結果で DP レベルの変化が WS，NWS の両耳に出現 したことを考えると, 三叉神経節からの遠心投射 ${ }^{19,20)}$ と 交叉性オリーブ蝸牛束の関与 ${ }^{22,26,27,28)}$ が十分考えられる. とくに中周波帯域については, 対側耳に雑音を負荷す ると遠心制御により抑圧されやすいとの報告 ${ }^{29)}$ があり， 
本結果も同様の傾向が示され, Shore ${ }^{30)}$ の三叉神経刺 激により蝸牛神経核が応答するとの報告を考えると，遠 心制御の可能性が示唆される.

側方移動における顆頭点の変化とWS耳, NWS 耳 のDPOAE との相関表は表 6 に示した。WS において $2531 \mathrm{HzDP}$ レベルと側方顆路角の間で有意な正の相関が 認められた．NWSにおいては全測定值で有意性は認め られなかった. 本研究の結果示された顆頭点の上下方向 の変化における作業側と非作業側との差違, 多様な变化 を示す側方顆路角と DP レベルとの相関は，聴覚路の機 能変化が単に顆頭点の前後的位置によるのではなく ${ }^{31)}$, 捻れを示唆すると考えられる。これらにより $2531 \mathrm{HzDP}$ レベルでは, 顆頭点の位置的変化とくに顆路角が示唆す る下靧頭の捻れに伴う蝸牛への影響の指標となる可能性 が考えられた。

\section{V. まとめ}

健常有歯顎者の閉口位と側方位のティンパノグラム, 歪成分耳音響放射を測定し，下顎側方移動に伴う蝸牛の 機能变化を検討した結果，下顎の移動による三叉神経の 感覚受容の変化が,蝸牛に投射される可能性が示唆され， この変化は DP レベルの測定によって把握可能と考えら れた.

\section{V. 文 献}

1) Wright, W. H.: Deafness as influenced by malposition of the jaws; J. Natl. Dent. Assoc., 12: 979-992, 1920.

2 ）松本敏彦：高度先進医療「耳鼻咽喉領域の機能障害 を伴った顎関節症に対する中耳伝音系を指標とした 顎位決定法」, 歯科評論, $63: 111-119,2003$,

3 ) 菊池康視: 歪成分耳音響放射による顎機能障害の客 観的評価, 日大口腔科学, $26: 139-145,2000$.

4 ）松本敏彦, 成田紀之, 小林久純ほか：耳小骨筋反 射による顎機能異常の病態評価, 日大歯学, 68 : 272-277, 1994.

5 ) 中庭敏博, 松本敏彦, 岸 高生: 顎関節症の耳痛発 症の機序，耳鼻臨床，96:219-224，2003.

6 ) 酒井勇司：中耳機能を指標とした下顎位の客観的評 価, 日大口腔科学, $20: 20-28,1994$.

7 ）大久保敦子, 篠田 誠, 松本敏彦: Dynamic Compliance による下頇位と耳小骨筋反射との関連，日 大口腔科学, $27: 304-311,2001$.

8 ) Ingervall, B. : Tooth contacts on the functional and nonfunctional side in children and young adults, Arch Oral Biol, 17 : 191-200, 1972.

9 ) Aull, A. E.: Condylar determints of occlusal patterns, J Prosthet Dent, 15: 826-846, 1965.

10）中野雅徳：側方滑走運動における顆路と歯牙路に関 する研究, 補緅誌, $19 ： 647-665,1976$.

11）松本敏彦：顎関節と耳の機能異常，日本学術会議50 周年記念 咬合学研究連絡委員会シンポジウム「生 命科学における咬合一咬合と全身の関わりを探る $-」, 50-70,2000$.

12）松本敏彦：下顎頭位が中耳伝音系と蝸牛系に及ぼす 影響, 日本学術会議咬合学研究連絡委員会シンポジ ウム「咬合と䫟関節症一咬合因子をどのように捉え るか一」, 31-38, 2004.

13）黑滝義之，大久保敦子，松本敏彦：開口運動の外耳 腔圧と動的コンプライアンスとの関係, 日大口腔科 学, $23: 347-351,1997$.

14）田沼達也, 松本敏彦, 池田 直: Immediate Side Shift の及ほす中耳機能の変化, 日大口腔科学, 18 ： 82-86, 1992.

15）熊谷重城, 大山健二, 稲村直樹ほか：カナマイシ ンによる蝸牛障害動物の DPOAE と外有毛細胞の 組織像との関連性, Audiology Japan, $36: 746-750$, 1993.

16）高坂知節，大山健二：耳音響放射の臨床応用に関す る最近の知見, 耳鼻臨床, $85: 673-681 ， 1992$.

17) Telischi, F. F., Stagner, B., Widick, M. P., et al.: Distortion-Product Otoacoustic Emission Monitoring of Cochlear Blood Flow, Laryngoscope, 108: 837-842, 1998.

18) Mom, T., Telischi, F. F., Martin, G. K., et al.: Measuring the Cochlear Blood Flow and Distortion-Product Otoacoustic Emissions during Reversible Cochlear Inschemia: A Rabbit Mo-del, Hear Res, 133: 40-52, 1999.

19) Vass, Z., Shore, S. E., Nuttal, A. L., et al.: Direct Evidence of Trigeminal Innervation of the Coch-lear Blood Vessels, Neuroscience, 84: 559-567, 1998.

20) Vass, Z., Shore, S. E., Nuttal, A. L., et al.: Trigeminal Ganglion In-nervation of the Cochlea-A Retrograde Transport Study, Neuroscience, 79: 605-615, 1997.

21) Sobhy, O. A., Koutb, A. R., Abdel-Baki, F. A., et al.: Evaluation of aural manifestations in temporo-mandibular joint dysfunction, Clin Otolaryngol, 29: 382-385, 2004.

22）鎌田善博：無難聴性耳鳴における耳音響放射者の臨 
床的検討，岩手医誌，52：101-110，2000.

23）松本敏彦, 菊池康視, 久保田佳孝ほか：耳音響放射 （OAE）による咬合性蝸牛神経機能異常の客観的評 価, 全身咬合, 4:82-92, 1998.

24）和田 仁, 小林俊光, 大山健二ほか：誘発耳音響 放射と中耳動特性との相関一誘発耳音響放射が最 も明瞭に測定できる入力刺激音周波数について一， Audiology Japan, 33 : 137-143， 1990.

25) Nagai, T., Tono, T.: Encapsulated nerve corpuscles in the human tympanic membrane, Arch Otolaryngol, 246: 169-172, 1989.

26) Lockwood, A. H., Salvi, R. J., Coad, M. L., et al.: The functional neuroanatomy of tinnitus: evidence for limbic system links and neural plasticity, Neurology, 50: 114-120, 1998.
27) Lockwood, A. H., Salvi, R. J., Burkard, R. F., et al.: Neuroanatomy of tinnitus, Scand Audiol Suppl, 51: 47-52, 1999.

28) Pinchoff, R. J., Burkard, R. F., Salvi, R. J., et al.: Modulation of tinnitus by voluntary jaw movements, Am J Otol, 19: 785-789, 1998.

29）泰地秀信, 小川茂雄, 岡本 健: DPOAE の安定性 と対側音による抑制, Audiology Japan, $40 ： 58-63$, 1997.

30) Shore, S. E., Kashlan, EL. H., Lu, J.,: Effect of trigeminal ganglion stimulation on unit activity of ventral cochlear nucleus neurons, Neuroscience, 119: 1085-1101, 2003.

31）松本敏彦, 小林久純, 佐藤 扇ほか：顎関節症にお ける耳症状と下顎頭偏位との関連, 日大歯学, 74 : 737-741, 2000. 